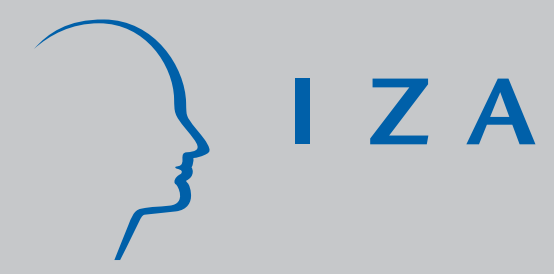

IZADP No. 4065

\title{
Atypical Work and Employment Continuity
}

J ohn T. Addison

Christopher J . Surfield

March 2009 


\title{
Atypical Work and Employment Continuity
}

\author{
John T. Addison \\ University of South Carolina, \\ Queen's University Belfast and IZA \\ Christopher J. Surfield \\ Saginaw Valley State University
}
Discussion Paper No. 4065
March 2009

\author{
IZA \\ P.O. Box 7240 \\ 53072 Bonn \\ Germany \\ Phone: +49-228-3894-0 \\ Fax: +49-228-3894-180 \\ E-mail: iza@iza.org
}

\begin{abstract}
Any opinions expressed here are those of the author(s) and not those of IZA. Research published in this series may include views on policy, but the institute itself takes no institutional policy positions.

The Institute for the Study of Labor (IZA) in Bonn is a local and virtual international research center and a place of communication between science, politics and business. IZA is an independent nonprofit organization supported by Deutsche Post Foundation. The center is associated with the University of Bonn and offers a stimulating research environment through its international network, workshops and conferences, data service, project support, research visits and doctoral program. IZA engages in (i) original and internationally competitive research in all fields of labor economics, (ii) development of policy concepts, and (iii) dissemination of research results and concepts to the interested public.
\end{abstract}

IZA Discussion Papers often represent preliminary work and are circulated to encourage discussion. Citation of such a paper should account for its provisional character. A revised version may be available directly from the author. 
IZA Discussion Paper No. 4065

March 2009

\section{ABSTRACT}

\section{Atypical Work and Employment Continuity}

Atypical employment arrangements such as agency temporary work and contracting have long been criticized as offering more precarious and unstable work than regular employment. Using data from two datasets - the CAEAS and the NLSY79 - we determine whether workers who take such jobs rather than regular employment, or the alternative of continued job search, subsequently experience greater or lesser employment continuity. Observed differences between the various working arrangements are starkest when we do not account for unobserved individual heterogeneity. Controlling for the latter, we report that the advantage of regular work over atypical work and atypical work over continued joblessness dissipates.

JEL Classification: J40, J60, J63, M50

Keywords: atypical work, open-ended work, employment continuity, unemployment, inactivity

Corresponding author:

John T. Addison

Department of Economics

Moore School of Business

University of South Carolina

1705 College Street

Columbia, SC 29208

USA

E-mail: ecceaddi@moore.sc.edu 


\section{Introduction}

Analysis of the consequences of atypical work (e.g. contracting, consulting, on-call, and temporary agency work) is controversial. This is particularly true for temporary agency work. Much of the early literature on these temporary work arrangements concluded that the jobs in question were dead-end, offering their incumbents little opportunity or incentive to invest in themselves or to develop productive job search networks. Such workers were characterized as confronting continuing job instability and ongoing skill deficits (Parker, 1994; Nollen, 1996; Blank, 1998).

More recently the research pendulum has if anything swung the other way, and even in Europe may have influenced the passage of legislation seeking to regulate the pay and conditions of agency temporary workers. ${ }^{1}$ A new, largely unpublished literature (e.g. García-Pérez and Muñoz-Bullón, 2002; Ichino et al., 2004; Kvasnicka, 2005; Zijl et al., 2004) has tended to suggest to the contrary that temporary jobs facilitate labor market advancement, reducing the time their incumbents spend in largely unproductive job search while also leading to longer term job attachment (via heightened human capital investment and improved labor market networks). But the new literature has come under challenge on technical grounds (e.g. inadequate modeling of the likely nonrandom selection of workers with different earnings capacities into atypical work) and because of its narrow focus on one job category.

The present exercise seeks to cast new light on one aspect of atypical employment, namely, its effects on employment continuity. ${ }^{2}$ The main contribution of the paper is inclusiveness; that is, it investigates the full range of atypical work arrangements, not just a subset thereof, and provides updated estimates of their effect on employment continuity using pooled data and panel estimates.

\section{Existing Research}

\footnotetext{
${ }^{1}$ That is, by contributing to the delay in the passage of laws. European Union mandates seeking to regulate atypical work go back more than one-quarter of a century. But the first atypical worker directives were not enacted into law until the late 1990s and covered only part-time work and fixed-term contracts (see, respectively, Official Journal, 1998, 1999). A mandate seeking to guarantee temporary agency workers on assignment equal pay and conditions to those of workers in the user undertaking doing the same job was mooted in 2002. Given its reach, this mandate proved more controversial. Its passage ultimately hinged on a series of 'external' and 'internal' concessions: the former to the British on opt-outs from yet more contentious legislation regulating working hours, and the latter through collectively negotiated arrangements permitting deviations from principle of equal treatment and derogations allowing member state freedom to exclude from the equal treatment principle occupational benefits such as sick pay and pensions and financial participation schemes (see Official Journal, 2008).

${ }^{2}$ Elsewhere we have considered the wage effects of atypical work arrangements; see Addison and Surfield (2007).
} 
Prior to the publication in 1995 of the Contingent and Alternative Employment Arrangement Supplement (CAEAS) to the Current Population Survey, U.S. research focused almost exclusively on a single alternative work arrangement, namely, agency temporary work. ${ }^{3}$ Agency temps were typically identified by their self-reported industrial code, giving rise to potential measurement error in circumstances where workers reported the industrial classification of the client firm rather than the temporary help agency. This early empirical literature reported that temporary help service workers experienced shorter (and coincidentally poorly-paid) spells of employment compared with workers in other industries (e.g. Davis-Blake and Uzzi, 1993; Parker, 1994).

In recognition of the limitations of worker-provided data prior to the CAEAS, Segal and Sullivan (1997) examined the impact of temporary work on employment continuity using data from Washington state's unemployment insurance program that maintains quarterly, employerprovided information on the employment history of workers covered by the system. Since the authors have longitudinal data (for 1984 to 1994), they observe repeated spells of employment for the same individual(s), allowing them to include an individual-specific intercept in their regression analysis and thereby help control for unobserved factors that might influence the decision to become a temporary worker.

The results obtained by Segal and Sullivan were mostly supportive of the earlier literature. That is, temporary help service workers were found to experience significantly shorter employment durations than those of workers in other industries. Moreover, roughly 40 percent of the observed spells of temporary employment ended with the worker entering into either unemployment or exiting from the labor force. ${ }^{4}$ For its part, inclusion of individual fixed effects had little impact on the duration of temporary employment, implying that unobserved individual heterogeneity did not contribute materially to the differential employment continuity of agency temporaries.

A more positive evaluation of temporary employment was reported in a study by Lane et al. (2003), using Survey of Income and Program Participation panel data, 1990-93. They sought to match at-risk (of welfare) temporary workers - defined as those who either received public

\footnotetext{
${ }^{3}$ Even though questions on atypical work arrangements were introduced into the 1994 National Longitudinal Survey of Youth.

${ }^{4}$ Among those who remained in employment, however, more than one half of temporary employment spells ending within six months were followed by regular employment.
} 
assistance or had family income below 150 percent of the poverty line in the previous year with control groups assembled from the regular worker population, using propensity score techniques based on demographic characteristics and employment histories. The authors found that although individuals who experienced a spell in temporary employment suffered worse employment outcomes than those who worked in open-ended employment, they did considerably better than similar workers who had a spell of unemployment. Specifically, comparing the unemployed who found temporary employment after one month with similar workers who were not employed in either month, the former had a 69 percent chance of being employed one year later and the latter only a 35 percent chance.

The two most recent U.S. studies also focus narrowly on the temporary employment option for disadvantaged workers. They reach differing conclusions. In an analysis of welfare recipients in North Carolina and Missouri - using samples for 1993/97 and 1997 respectively, observed eight quarters before and eight quarters after the sample period(s) - Heinrich et al. (2005) again report that individuals who go to work for temporary agency firms fare substantially better than those who fail initially to find work. Moreover, although recipients in temporary jobs have fewer quarters in which they receive positive earnings than other employed recipients, the authors' analysis confirms that after two years are no less likely to be employed (and have earnings close to the to these workers). Only in terms of welfare recidivism is their performance inferior to regular workers - and, to repeat, for all outcomes it remains much better than for initially/currently unemployed workers. The bottom line from this study is that temporary jobs provide a path to other industries with greater employment stability (and higher earnings).

Rather different results are provided by Autor and Houseman (2005) in a unique analysis of administrative data from the Michigan Work First program for welfare recipients that are linked with that state's UI wage records data base. Employment continuity (quarters of employment) are charted for up to two years - as are payroll earnings. The sample comprises 38,689 Work First spells initiated between 1999 and 2003. The study is notable for its quasiexperimental status. Under Michigan's workfare plan, employment services are provided by nonprofit private or public sector agencies whose placement practices vary significantly but who otherwise offer similar services. In circumstances where multiple such contractors are involved in the provision of services within a geographic district they take turns in enrolling applicants. 
Accordingly, the distribution of participants among contractors is random, providing a new experimental context for the evaluation of the employment service of temporary employment.

Autor and Houseman obtain similar results to the modern (welfare) literature for simple OLS specifications. That is to say, the post-assignment employment continuity of temps exceeded that of the initially unemployed over time (as did their earnings), while differences between direct hires and temps were muted. However, the authors' instrumental variables regressions (wherein contractor-by-year dummy variables replace the direct hire and temporary work status variables) yielded very different results beyond the first post-assignment quarter. And the disparities increased in the follow-up period. Thus, for example, over a two-year interval temporary help job placements were associated with insignificant increases in employment continuity (and earnings losses) vis-à-vis those receiving no placement, while direct hire placements produced major increases in total quarters of employment (and earnings). The impression that temporary jobs do not improve and may actually harm labor market outcomes was sharpened by the authors' analysis of marginal treatment effects which suggested among other things that marginal temporary worker gains in employment (and earnings) during the first year come at the cost of sacrificed employment (and earnings) in direct-hire jobs. Any firstquarter benefits associated with 'temping' are eliminated within the first year. In sharp contrast, direct-hire placements produced strong and continuing gains, with the suggestion that welfare recipients might be better advised to eschew temporary help jobs and search for open-ended employment at the outset, agency temporary employment being a poor substitute for continued unemployment.

The issue raised by this sole experimental study is whether non-experimental studies are biased by the selection of workers into job types on the basis of unobserved characteristics or simply reflect a difference between marginal and average treatment effects. We note parenthetically that the authors of this careful treatment pay especial attention to eliminating other factors that might influence their results, namely, unmeasured differences between contractors and the issue of parameter instability.

It is appropriate at this stage to briefly mention a number of European studies of the effects of temporary employment. The most recent European research points in a fairly optimistic direction. For Britain, in an analysis of job duration and reason for exit using data from the British Household Panel Survey for 1991-97, Booth et al. (2002) report that fixed-term 
contracts provide effective stepping stones to permanent jobs (and only transitory reductions in earnings). For Italy, using propensity score matching methods, Ichino et al. (2004) find that relative to starting off unemployed being in a temporary help job significantly improves the probability of the worker finding permanent employment within 18 months. And for the Netherlands, Zijl et al. (2004) advance a formal structural model of transitions into open-ended employment and observe that taking a temporary job materially reduces jobless duration while facilitating subsequent job continuity. To begin with, newly unemployed temporary workers have a somewhat lower rate of transition into regular employment than do unemployed workers, but after 18 months the escape rate from temporary employment exceeds that from unemployment, suggesting an accretion of human capital assets and the formation of social networks. Interestingly, to the extent that they use temporary work, the stepping stone effect is found to be somewhat higher for lower educated individuals than for their more educated counterparts and for male ethnic minorities than for the native population.

Whatever the progress made in investigating the employment consequences of atypical work, this near exclusive focus on temporary agency employment necessarily presents only a partial picture of atypical work. In concluding this literature review, therefore, we turn to the one study that considers a more comprehensive range of alternative work arrangements. Taking advantage of the then newly-administered CAEAS, Houseman and Polivka (2000) include in their investigation not only agency temporaries but also direct-hire temporaries, on-call workers, contract workers, and independent contractors. They were able to identify the labor market outcomes of workers by matching the February 1995 CAEAS to the subsequent CPS surveys for March 1995 and February 1996. Since their primary focus was upon the job stability associated with atypical work, those initially observed as being unemployed or out of the labor force were excluded from their analysis.

Houseman and Polivka's results seem to be more in line with earlier U.S. research. Specifically, they find that many atypical workers are likely to find themselves transitioning into both labor market inactivity and joblessness at rates that are significantly greater than those observed for (full-time) regular employment. But these effects are not uniform. Agency temporaries fare the poorest: the likelihood they will be unemployed after one year is roughly two to eight percentage points greater than is the case for those engaged in open-ended employment. For direct-hire temps and on-call workers the corresponding increases in the 
probability of entering joblessness are three to four and four to five percentage points, respectively. Only independent contractors are (about one percentage point) less likely to be observed unemployed than are regular workers.

The present treatment seeks to tackle two limitations of the extant literature: its narrow scope and dated information. Accordingly, we shall look to a number of atypical work arrangements, use newer CAEAS/CPS information that we shall supplement with data from the National Longitudinal Survey of Youth, 1979 Cohort. We shall also include those individuals who are initially unemployed and out of the labor force, allowing us to address the issue of employment as opposed to job continuity.

\section{Data and Methodology}

The Contingent and Alternative Employment Arrangement Supplement to the Current Population Survey (CAEAS/CPS) is a large, nationally representative dataset. It was first conducted in February 1995 and is administered biennially. One key advantage of the CAEAS/CPS is its large number of observations - important given the relatively small number of workers engaged in certain atypical work arrangements (contract and on-call work in particular). The data contained in the parent CPS survey(s) conducted one year later is used to identify labor market outcomes.

Our second and overlapping source of data is the National Longitudinal Survey of Youth, 1979 Cohort (NLSY79). Although the NLSY79 tracks a narrower age cohort - it covers workers aged 29 to 34 years in 1994 - it does contain richer information on labor market histories; in particular, on length of time employed. The NLSY79 also allows us to follow individuals for longer time intervals and potentially to draw stronger inferences about the labor market implications of atypical work.

The CAEAS/CPS Data. We extracted one cross section from each of the four CAEAS/CPS surveys issued from 1997 until 2005. ${ }^{5}$ Each cross section was then linked to the parent CPS issued exactly one year later. (We also linked the CAEAS to the Displaced Worker Survey, conducted in the February of the following year for three of the four cross sections. Space constraints dictate that we will only summarize the results of this exercise.)

\footnotetext{
${ }^{5}$ Budgetary cuts prevented the CAEAS/CPS from being issued in 2003, while the 1995 CAEAS/CPS was not usable because of a change in the household identifier in September 1995 that prevented us from matching it with the subsequent CPS survey.
} 
The rotational design of the CPS has households being actively interviewed for four months, rotated out for eight months, and then re-interviewed for four additional months prior to being permanently rotated out of the survey. This pattern limits the number of households identified in the CAEAS that can be matched to the CPS survey administered one year later. Since there is no overlap of individuals contained in each of the four cross sections, we shall combine them into single pooled sample.

We classify workers into one of nine mutually exclusive work and non-work categories. The first two work arrangements pertain to open-ended employment and comprise regular workers and screened workers. (Regular workers are those who are hired directly into openended employment without having been first screened through an atypical work arrangement.) Following the convention established in the literature, we next distinguish between five types of atypical employment: agency temporaries, direct-hire temporaries, on-call workers, contract company workers, and independent contractors. Our two residual categories are those initially reported as being unemployed or out of the labor force.

Using regular workers as one basis for comparison, we can directly assess if atypical work offers employment that is more (or less) stable than open-ended employment. Use of the initially unemployed as a second reference category, allows us to determine whether being employed in an atypical arrangement affords workers with greater (or lesser) employment continuity than results from continued search.

Matching the CAEAS data with the CPS provides our principal measure of employment continuity, namely, the labor market status of the worker one year later. ${ }^{6}$ The three possible outcomes identified in the subsequent CPS are: employed one year later, unemployed one year later, or out of the labor force one year later. A multinomial logit choice model is adopted to analyze the employment outcome. Ceteris paribus, the multinomial logit will provide us with an estimate of the probability of observing an individual with a particular characteristic in a given outcome relative to the probability of observing an individual with a reference characteristic being observed in that outcome. For example, we can determine how much more (or less) likely

\footnotetext{
${ }^{6}$ Matching CPS data with the Displaced Worker Supplements to the CPS provides us with another measure of employment continuity: whether or not the worker was displaced over the course of the following year. Results for this second measure are provided parenthetically below.
} 
an agency temporary will be employed one year later than will a regular worker (or an initially unemployed worker).

Turning to the other regressors, we have data on traditional demographical controls such as age, education, ethnicity, and gender. We also use information on the number of children in the household under six years of age on the grounds that atypical work offers individuals with pre-school children a more flexible work form potentially better suited to their needs than regular employment. If so, it would not be surprising to see a diminished employment continuity attaching to atypical work. Next, for those who held a job of some kind, be it open-ended work or atypical employment, we can also include controls for industry and occupation (set equal to zero for those individuals we initially observe as being unemployed or out of the labor force). The CAEAS data also allow us to construct a variable that is analogous to a worker's tenure (in years). For those engaged in regular, screened, and direct-hire temporary work, it is the actual tenure acquired by the worker with his or her employer. For agency temporaries and contract company workers, the variable measures the number of years that the individual has been with his/her agency/contract company, which may not be the same as the tenure accumulated with the client firm reported at the time of the contingent worker survey. For independent contractors and on-call workers, the variable simply measures the time incumbents have been engaged in these work arrangements. ${ }^{7}$

The NLSY79 Data. Our second data set is used to derive additional insights into atypical work and its stability. Specifically, the NLSY data permit examination of a longer time interval - up to four years - to evaluate the implications of atypical work for at least some aspects of employment continuity. Note that use of the NLSY79 also enables us to address one of the concerns attaching to the use of the matched CAEAS/CPS data, namely, the potential bias that arises from our inability to completely match respondents from one survey to another. ${ }^{8}$ We use the 1994 to 2002 waves of the NLSY79.

\footnotetext{
${ }^{7}$ The only restriction imposed on the data, other than the exclusion of individuals with any missing information, was age related: we excluded workers under (over) the age of twenty-five (sixty-five) years, so as to avoid contamination stemming from more fundamental differences in labor market attachment.

${ }^{8}$ For example, workers who were initially unemployed may have moved to take advantage of better labor market opportunities elsewhere and thus be missing from subsequent CPS surveys. (Respondents are selected for inclusion in the CPS on the basis of their address, with those who leave the address being replaced in the survey by the new occupants.) In such cases, the CAEAS/CPS comparisons will overstate the potential benefits of atypical work over joblessness.
} 
We can now classify individuals into one of eight mutually exclusive work and non-work arrangements. As is the case for the CAEAS/CPS, we can identify regular workers, screened workers, agency temporaries, and direct-hire temporaries. But the NLSY79 does not distinguish between contract workers and independent contractors, only allowing us to work with a composite contractors/consultants category. Another difference from the CAEAS is the category of other work types, of which the most common variant is self-employment. The two remaining categories are again those initially unemployed and initially out of the labor force.

From the NLSY79 we form our second principal measure of employment continuity: fraction of time employed. It is obtained by taking the weeks of time that the individual reports being employed between interviews and dividing them by the number of weeks between those interviews. This standardized ratio is, arguably, a better gauge of employment continuity than is labor market status at a single point in time. Since we have repeated observations on individual employment spells, we can measure the fraction of time a worker is employed over two and four year intervals after each of 1994, 1996 and 1998 interviews. ${ }^{9}$ These repeated observations allow us to adopt panel estimation techniques in analyzing the fraction of time a worker has been employed.

Finally, the work diaries maintained by the NLSY79 respondents also provide us with some additional human capital controls not found in the CAEAS/CPS data. Specifically, we have direct data on a worker's (cumulative) general labor market experience as well as his or her tenure on the current job. The NLSY79 gives the actual number of weeks that the respondent has been employed since entering the survey, as well as the actual number of weeks employed with the current employer (or employment type in the case of contractors/consultants and other work types). Moreover, we can also form a standardized measure of the number of jobs held by individuals by dividing the reported total number of jobs held by (cumulative) general labor market experience. This jobs measure can be also viewed as an inverse proxy for the attractiveness of the worker to an employer. Finally, the selfsame restrictions stemming from

\footnotetext{
${ }^{9}$ The 2000 and 2002 waves of the NLSY79 were unusable for the multinomial logit component of our employment continuity analysis. They do not provide information on the three labor market end-states, only indicating on this occasion whether or not the worker was employed.
} 
incomplete demographic, industrial, and occupational characteristics apply here as for the CAEAS/CPS samples. ${ }^{10}$

\section{Findings}

Results from the CAEAS. Simple descriptive statistics on the employment status of incumbents of the various CAEAS job categories one year after administration of the survey are given in Table 1 for the pooled sample. The main features of the cross tabulations are as follows. First, there is the general point that although regular or open-ended employment is associated with greater employment stability than atypical work as a whole, atypical work is not a monolithic entity. Second, there is little indication that initially serving an employer in an atypical work capacity before being inducted into open-ended employment serves to increase the employment stability enjoyed by these screened workers: their slightly higher employment rate after one year is not statistically different from that of workers hired directly into regular employment. Third, agency temporaries, on-call workers, and to a somewhat lesser extent direct-hire temporaries are clearly less likely than regular workers to be holding a job of some kind one year later, reflecting their higher exit rates into inactivity and not just unemployment. Fourth, contract workers and independent contractors are located at the other end of the spectrum. Their employment probabilities after one year resemble regular employment. Indeed, their transitions into unemployment can even be lower than for regular employment. Finally, the initially unemployed and the economically inactive record the least favorable outcomes. Both labor market states indicate persistence, especially the latter. Summarizing, we find that some atypical workers are engaged in more precarious employment than are regular workers. To proceed further, we turn to our cet. par. analysis.

\section{(Table 1 near here)}

Results of fitting the multinomial logit model to the CAEAS data are given in Table $2 .^{11}$ Recall that the coefficient estimates represent the impact that a worker possessing a particular characteristic (including being in atypical work) has on the probability of that individual subsequently being observed in a particular reference outcome (such as employment) than a

\footnotetext{
${ }^{10}$ We note that the characteristics of atypical workers in the NLSY79 broadly mimic their CAEAS counterparts. Descriptive statistics and probit regression results for both datasets are available from the authors upon request.

11 These are summary findings. The full results for Table 3 (and all subsequent tables) are available from the authors upon request.
} 
worker with the reference characteristic. Table 2 uses two such reference characteristics. The first set of coefficient estimates (given in first and third columns) gives the likelihood that atypical workers are to be either employed or inactive, respectively, than unemployed one year later relative to the corresponding rates observed for regular workers. The employment stability of atypical work is here assessed against the yardstick of open-ended employment. The second set of coefficient estimates (in the second and fourth columns of the table) obtain when using initial unemployment as our reference characteristic. This latter exercise helps us determine whether engaging in atypical work is preferable to (continued) job search.

(Table 2 near here)

To give a concrete example, take the coefficient estimate for direct-hire temporaries in the first column of the table. We can see that such workers are less likely to be employed one year later than they are to be unemployed when compared with regular workers. The marginal effects, given in brackets, measure the independent probability that a worker possessing a particular characteristic being observed in that labor market state relative to the reference category. Again in the case of direct-hire temporaries, such workers are seven percentage points less likely to be employed than are regular workers. Recall that we are no longer conditioning this estimate on the likelihood of being in the reference outcome of unemployment (as is the case for the coefficient estimate).

Although similar results are reported for on-call workers, and consistent with the descriptive material in Table 1, our cet. par. results confirm that atypical workers are not a monolithic group. Observe that contract work has no unfavorable labor market implications compared with regular employment, while there is some weak evidence that independent contractors enjoy a greater degree of employment continuity than regular workers. ${ }^{12}$ As was the also the case in Table 1, we find little evidence that initially serving an 'apprenticeship' in an alternative work arrangement increases employment continuity. That is, the coefficient estimate

\footnotetext{
${ }^{12}$ Note that, in the case of independent contracting, we obtain an estimate of the marginal effect that is of opposite sign to the coefficient estimate. This result is possible when there is a dominant relative outcome associated with one particular characteristic. In this case, it would appear that independent contractors are much less likely to be unemployed than they are to be employed relative to the corresponding likelihood for regular workers. As was evident in Table 2, only a very small fraction of independent contractors are subsequently reported as being unemployed. Rather, they tend to be either employed or to quit the labor force one year later. When we focus solely upon the independent likelihood of being observed as employed one year later, therefore, we find that independent contractors are about three percentage points less likely to be employed than are regular workers.
} 
for screened workers, although of the expected positive sign, lacks significance at conventional levels.

As for the initially jobless, these individuals record a 22 percentage point reduction in the probability of being employed vis-à-vis regular workers. For its part, having initially left the labor force serves to decrease the likelihood that such individuals will be observed holding a job one year later by nearly fifty percentage points.

The coefficient estimates contained in the third column of Table 2 chart the likelihood that a worker possessing a particular characteristic will move out of the labor force than be unemployed one year later relative to the corresponding likelihood for a regular worker. With the exception of independent contractors, there is scant evidence of statistically significant differences in labor force attachment across the various forms of atypical work. Consistent with the tabulations presented in Table 1, those out of the labor force at the time of the CAEAS are more likely (47 percentage points) to be economically inactive than are regular workers.

In sum, we have found that regular work is associated with a greater degree of employment stability than is the case for direct-hire temporaries and on-call workers. But agency temporaries, contract workers and independent contractors are as likely or even slightly more to be employed than to be unemployed one year later compared to regular workers. Also, there is every indication that atypical work provides workers with greater employment stability than initial unemployment.

But all of this pertains to the reference characteristic of open-ended employment. The coefficient estimates in the second column of Table 2 represent the likelihood that a worker in either an atypical job or open-ended employment will be employed rather than be unemployed one year later when compared with the corresponding likelihood for an initially unemployed individual.

It can be seen that agency temps are, in fact, more likely to be employed one year later than are the initially jobless. The estimated marginal effect would suggest that taking an agency temporary position increases the probability of holding employment of some kind one year later by twelve percentage points vis-à-vis those initially unemployed. Similar advantages over the initially unemployed attach to direct-hire temping (fifteen percent) and on-call work (fourteen percent) in this regard. We are less surprised to observe such favorable relative outcomes among contract workers and independent contractors since they appear to enjoy the same employment 
stability as regular workers. Nonetheless, these two alternative work arrangements increase by twenty-four and twenty percentage points, respectively, the likelihood that their incumbents will be employed relative to the initially unemployed. Regular and screened workers have an increase in their employment probabilities that are of the same magnitude.

Although in the fourth column of the table, we obtain positive coefficient estimates for regular and screened workers exiting the labor force, these results should not be construed as implying such individuals exhibit lesser attachment to the labor market than do the initially unemployed. Thus, when we examine the unconditional estimates - the marginal effects - we observe that they are indeed less likely to be moving out of the labor force than are the initially unemployed. Again, given the very strong propensity of the initially jobless to remain in this (unemployed) labor market state, we will estimate coefficients and marginal effects that may not be of the same sign. Indeed, observe that the five atypical work forms also appear to point to weaker labor market attachment (than for the initially unemployed), but in all cases the marginal effects are again negative.

Turning briefly to the controls, we see that the coefficients for tenure and its quadratic are of the expected sign and statistically significant. Each year of tenure that workers accumulate with their employer increases the probability of being employed one year later by slightly more than one percentage point. For its part, the coefficient estimate for the average unemployment rate in a state over the course of the year - designed to hold constant labor market conditions suggests that higher levels of joblessness serve to decrease the likelihood that a worker will be employed one year later. Each one percentage point increase in the unemployment rate decreases the likelihood of holding a job by about one and one-half percentage points. However, although the coefficient estimates for the number of children under the age of six in the household are of the expected sign, they lack significance at conventional levels. Note that we report only two sets of results for the labor market controls since the coefficients are not influenced by the reference category.

Finally, the likelihood ratio tests at the foot of Table 2 serve to indicate that atypical work is not a homogeneous grouping. The tests reject the possibility, at the .01 level, that the five different forms of atypical work hold uniform implications for a worker's subsequent labor market outcomes. It would appear that we can aggregate agency temporaries and their direct-hire counterparts into one composite category, as well as fold contract workers in with independent 
contractors. What appears to be the case, however, is that contracting work is dissimilar from either temporary or on-call work, in its labor market outcomes. Moreover, the final hypothesis test rejects the possibility that open-ended employment affords workers with the same degree of employment continuity as atypical work as a whole. The on-net interpretation is that regular work is preferable to atypical work which is, in turn, preferable to being unemployed. ${ }^{13}$

Results from the NLSY79. Descriptive statistics on the employment status of the various work arrangements identified in the NLSY79 data are presented in Table 3. Workers are classified according to the work arrangement in which they are employed at the beginning of each cross section. Although the same individuals are contained in each cross section, they may be employed subsequently in a different work arrangement.

(Table 3 near here)

Generally, the NLSY79 descriptive statistics broadly resemble those reported earlier for the CAEAS/CPS. Thus, the two types of open-ended employment are associated with higher levels of (subsequent) employment relative to atypical work. In the case of contractors/consultants, the probability that they will become unemployed is actually lower than that for regular workers and likely reflects their greater propensity to leave the labor force. More than two-thirds of those who were initially unemployed are in employment two and four years later. Such individuals evince unemployment rates that are significantly higher than those associated with either regular or atypical work. And over one-half of non-participants remain out of the labor force at the end if each interval.

Our third and final measure of employment stability is reported in the last row of each of the panels in Table 3, namely, the fraction of time between each interview that the respondent reported being employed. Open-ended employment is again associated with a higher level of employment continuity relative to temporary work, with contractors/consultants more or less on

\footnotetext{
${ }^{13}$ As noted earlier, we also performed a parallel exercise for the reference outcome probability of displacement over the course of one year, using the same reference characteristics. A standard (dichotomous) logit model was used to analyze the displacement phenomenon, the dependent variable being set equal to one if, over the course of a year, a worker lost his or her job due to displacement, zero otherwise. The main results of our logistic estimation exercise were twofold. First, differences between atypical work per se and regular employment were confined to direct hire temporaries who fared worse and independent contractors who fared better. Second, using initial unemployment as the reference characteristic, it would appear that atypical work does very little to improve a worker's relative employment stability. Only screened and regular employees (plus independent contractors) were observed to have lower rates of displacement. For this measure of employment continuity, at least, atypical workers fare just as poorly as those who continued their job search. Full results are again available upon request.
} 
a par with regular workers. Over the course of two years, regular and screened workers are employed about 94 percent of the time, or some 22.6 months. For their part, agency temporaries report being employed 78 to 81 percent of the time for the two-year cross sections. For the residual non-employment categories, the measure of employment continuity is lowest of all, although in each case employment rates increase the longer the cross section.

(Table 4 near here)

Multinomial logit regressions of the labor market outcomes after two years are provided in Table 4. The estimates were obtained by aggregating both of the usable two-year cross sections into a single pooled sample. Use of regular workers as the reference characteristic uncovers little evidence that atypical work yields significantly different labor market outcomes, ceteris paribus. From the first column of the table we see that being employed in either type of temporary work or in contracting/consulting neither increases nor decreases the likelihood that its incumbents will be employed two years hence rather than being unemployed when compared with regular workers. And from the third column of the table, there is little to suggest lesser labor market attachment on the part of atypical workers. Taken as a whole, therefore, these findings suggest that the distribution of outcomes for agency and direct-hire temporaries and contractors/consultants are much the same as for regular workers. Only those holding other work types are (about five percentage points) less likely to be observed holding employment two years later than are regular workers. It is the initially unemployed that fare particularly poorly vis-à-vis regular workers. Specifically, they are some nine percentage points less likely to be subsequently employed than are regular workers. Like the initially unemployed, those initially out of the labor force are less (more) likely to be employed (out of the labor force) two years later than are regular workers.

The second and fourth columns of Table 4 use the initially unemployed as the reference category. Evidently, regular, screened, agency temporary, and contracting/consulting workers are all more likely to be employed two years later than they are to be unemployed compared with the initially unemployed. But those who initially hold a job of any kind fail to display different attachment to the labor market than the initially unemployed.

The effects of the controls are mixed. General labor market experience apparently plays little or no role in explaining the subsequent employment rates experienced by our NLSY79 respondents, but does reduce the likelihood that workers will subsequently leave the labor force. 
Unsurprisingly, tenure is associated with a higher probability of being employed: each year of employment that a worker acquires with his or her employer increases the probability of holding a job two years later by slightly more than one percentage point. As for those individuals who held a larger number of jobs in the past, it would appear that they experience diminished future employment stability. Each prior job held decreases the likelihood that a worker will be observed in employment by about one percentage point. Contrary to the CAEAS/CPS results, local labor market conditions are no longer statistically significant, ${ }^{14}$ although the presence of young children does serve to increase the likelihood a worker will subsequently leave the labor force.

The first row of hypothesis tests at the foot of the table suggests that the distribution of outcomes for agency temporaries is not significantly different from that of direct-hire temporaries. Unlike the CAEAS/CPS results, however, it would seem that one can now aggregate the various types of atypical work into one composite category (second row entries). The findings in the final row suggest that atypical work and the two forms of open-ended employment hold different implications for future labor market outcomes.

(Table 5 near here)

Turning next to the longer, four-year cross section in Table 5, we uncover further evidence that initially holding employment of some kind may be preferable to initial unemployment. Further, when using regular employment as our reference characteristic, we observe that atypical workers experience not dissimilar labor market outcomes from regular workers. $^{15}$

We now see a suggestion that those who were initially screened for a regular position through atypical work are slightly more likely to be employed in 1998 than they are to be unemployed when compared with those hired directly into regular work. Initially serving one's employer in an atypical work arrangement increases the probability of being employed four years later by two percentage points compared with regular workers. We also see that those who are initially unemployed are (around twelve percentage points) less likely to be holding employment of some kind four years later than are regular workers. On the other hand, the

\footnotetext{
${ }^{14}$ Although we note that the NLSY79 does not report the unemployment rate in continuous form, necessitating the deployment of categorical variables.

${ }^{15}$ Notice that we now fold agency temporaries and direct-hire temporaries into a single composite category as there are no agency temporaries recorded as unemployed in 1998.
} 
negative coefficient estimate for those initially out of the labor force is not statistically significant.

Using the initially unemployed as the reference category in the second column of Table 5 indicates that not only regular and screened workers are significantly more likely to be observed as being employed after four years than are the jobless but also temporary workers as well. Finally, as regards the out of the labor force outcome in the last two columns of the table, we observe that only the economically inactive have a heightened probability of being inactive four years later.

The results of the controls are broadly as expected. Thus, tenure is positively correlated with the probability of being employed four years later, while experience is negatively associated with labor market withdrawal (if not employment). Again, having held a large number of jobs in the past reduces (by about one percentage point) a worker's (ongoing) employment stability over the course of four years. As was the case in our discussion of worker transitions over two years, the coefficient estimates for the (categorical) unemployment variables lack significance throughout. Increases in the number of small children serve only to influence the likelihood of quitting the labor force.

We now turn to our final measure of employment continuity, replacing the comparison of an individual's labor market status at a subsequent point in time with the fraction of time spent employed over the respective two- and four-year intervals. We adopt panel data estimation techniques to allow for the estimation of both a random and a fixed effects specification. Each model allows for the cross-correlation in the error term that arises when we have repeated observations on the same individual. The fixed effects linear model improves upon the random effects specification in allowing for an individual-specific intercept that should capture the effect that unobserved heterogeneity - such as worker motivation or ability - has on employment continuity. This unobserved heterogeneity may be particularly problematic if it is biasing our results regarding the amount of time a worker is employed between the various waves of our NLSY79 data.

\section{(Table 6 near here)}

The results are given in Table 6, the first four columns of which contain the pooled twoyear cross sections and the last four columns the pooled four-year cross sections. Throughout we use the same reference categories as before. Beginning with the two-year results, we observe that 
both types of temporary workers are employed for less time than are regular workers. The estimated coefficient for agency temporaries implies that initially being employed in this work arrangement serves to reduce by about 4.2 percentage points the fraction of time spent in employment over a two-year interval vis-à-vis regular workers, ceteris paribus. This means that an agency temp is employed for about 1.1 months less than a comparable regular worker. Directhire temporaries fare even worse: they are employed 8.5 percentage points less than regular workers. Engaging in a work form other than open-ended or atypical work appears to reduce by 3.6 percentage points the time that an individual will be employed over the course of two years. But no such deficit obtains for contractors and consultants - or any corresponding advantage in the case of screened workers.

The results in the second column of the table confirm that workers in employment of any kind spend more time in employment over two years than their initially unemployed counterparts. Specifically, agency (direct-hire) temps are employed eighteen (fourteen) percentage points more than the initially unemployed. For contractors/consultants, the corresponding advantage is about twenty-two percentage points. As expected, workers engaged in open-ended employment, be it regular or screened, enjoy among the greatest degree of employment continuity. Only the initially economically inactive are employed for less than the initially unemployed: the disparity is around twenty-three percentage points.

The labor market variables are largely of the expected sign. Having greater general labor market experience increases the percentage of employed time, as do greater levels of tenure with a firm. Those who report having a greater number of jobs in the past appear to not be significantly impacted, although having (additional) children under six in the household does serve to materially reduce the fraction of the two years that a worker reports being employed.

Turning to the fixed effects results (in columns 3 and 4 of Table 6), we see that the estimated coefficients are clearly diminished in absolute magnitude, implying that unobserved characteristics are biasing our results. Workers engaged in either atypical or regular work may be more able workers or possess other characteristics that are associated with greater employment stability. Abstracting from other work types, comparing the results presented in column 3 with those in column 1, only the coefficient estimate for direct-hire temporaries retains its significance - and its absolute magnitude is halved. Comparing the results contained in column 4 with those in column 2, there are still generally positive returns to atypical work per se but the benefits in 
terms of time spent employed are again halved after allowing for unobserved heterogeneity. And in one case - direct-hire temporaries - the coefficient estimate is not statistically insignificant. For the two types of jobless individuals, we see that much of their seemingly-reduced employment continuity again stems from unobserved heterogeneity. When the fixed effect estimator is used, both coefficients are reduced by more than one-half in absolute magnitude compared with the random effects estimates.

Turning to the four-year results in the last four columns of the table, we find that atypicals when compared with regular workers are (with one exception) employed for similar intervals. That is to say, the results presented in column 5 of the table imply that both agency temps and contractors/consultants experience no penalty over a four-year period when compared to their counterparts in open-ended employment. Only direct-hire temps are less continuously employed: about 4.5 percentage points (or some nine months) less than regular workers. Although of a lesser magnitude than the two-year results, our two types of initially jobless individuals still face a significant disadvantage relative to regular workers. Those initially unemployed (out of the labor force) are employed for ten (twenty-four) percentage points less than individuals who are initially employed in regular work.

The results presented in column 6 of the table suggest that taking a job of any kind, be it regular or atypical, serves to increase employment continuity over that experienced by the initially jobless. Workers in both types of open-ended employment, as well as contractors/consultants, are employed for about ten percentage points more than the initially jobless, while agency (direct-hire) temporaries have employment rates that are approximately eight (five) percentage points higher.

As was the case with our two-year results, we find that the random effects estimator produces coefficient estimates that are sharper in absolute magnitude than the fixed effects. After controlling for unobserved heterogeneity, there appears to be no difference between regular and atypical workers (column 7). More importantly, for the two types of jobless individuals, the fixed effects estimator produces coefficient estimates that are much reduced, implying that a good deal of the disparity between these two labor market states and regular work can be attributed to something other than status.

Finally, the advantage that those who initially held a job might have over the initially unemployed vanishes once we take into consideration unobserved heterogeneity. In contrasting 
the results contained in column 8 with those in column 6 , the suggestion is that those who initially held a job might be more able individuals or have more favorable (unobserved) characteristics which result in greater employment continuity than the initially unemployed.

The results of the hypothesis tests located at the foot of Table 6 are not surprising. When we fail to take into consideration unobserved heterogeneity, we find that aggregating atypical workers into one composite group is inappropriate. The results obtained from the fixed effects models would suggest that, after controlling for unobserved worker characteristics, there are no significant differences observed across the different atypical work forms.

One of the concerns of the fixed effects estimator is that if the unobserved heterogeneity is changing over time (e.g. one's preference for a particular work type), then the results are still going to be biased. We sought to take this concern into consideration by including number of pre-school children in the household. Presumably, their presence might make some types of atypical work more attractive given their flexibility in scheduling or hours. We find that, for both the two- and four-year results, the coefficient estimates of this variable are both statistically significant and negatively-signed. The fixed effects estimator produces coefficient estimates that are sharply lower in magnitude but generally significant.

Our analysis of the NLSY79 data provides some support for a more positive view of atypical work as a whole, at least over the medium-term. The evidence obtained from the multinomial logits would imply that the distribution of employment outcomes after two (and four) years is no different for atypicals than for regular workers. And both types of worker are more likely to be observed in employment at the end of either two or four years than are the initially jobless. In analyzing the fraction of time employed over a two-year period, however, we uncover evidence that atypicals are employed less continuously than are regular workers. Nevertheless, this disadvantage is greatly mitigated once unobserved heterogeneity is taken into consideration, while the observed advantage associated with atypical employment over the initially unemployed remains. Over the course of four years, we see that only the initially inactive experience lower employment continuity when we allow for unobserved heterogeneity.

\section{Conclusions}

At first blush, our analysis of both the CAEAS/CPS and much of the NLSY79 data provides support for the use of atypical work as a means of extending employment continuity 
and stability relative to continued job search. That is to say, we find that atypicals of all stripes are more likely to be employed at subsequent periods in time than the initially unemployed. In addition, these work arrangements might increase the amount of time spent in employment.

However, when we compare the employment stability of atypical work with that of openended employment, the evidence is mixed. The CAEAS/CPS results would suggest that temps and on-call workers are seemingly less likely to be subsequently employed after one year than are regular workers. The NLSY79 results, however, fail to produce any significant coefficient estimates over longer intervals. We can rule out one potential explanation for this: the limited cohort contained in the NLSY79 data. When we re-estimated the multinomial logit using CAEAS/CPS data restricted to the age cohort contained within the NLSY79, the results were broadly as before. In short, it is not cohort that is producing the differences between the two surveys.

It may be tempting to conclude from the multinomial logits that, when faced with continued job search and an offer of atypical work, atypical work is the preferable outcome. This also appears to be the case using our final duration-based measure of employment stability at least over a two year interval. That is to say, even after controlling for unobserved worker characteristics, there still is a significant advantage from opting to take atypical work over continued job-search. Over a longer four-year interval, however, much of the "benefit” enjoyed by atypicals over the initially unemployed dissipates. Equally on this measure, over the same time period, differences between regular work and atypical work disappear.

The bottom line of the present study therefore is that the sharpest differences between the atypical workers, regular workers and initially unemployed workers are found when one does not account for unobserved individual heterogeneity. Much, but not all of this disparity is, explained by unobserved characteristics - such as work preferences or worker ability - of the workers who are filling the work arrangements. Given this result, further investigation of why individuals end up in the various forms of atypical work is clearly warranted. 


\section{References}

Addison, John T., and Christopher J. Surfield. 2007. “Atypical Work and Pay.” Southern Economic Journal 73 (April): 1038-1065.

Autor, David H and Susan N. Houseman. 2005. "Do Temporary Help Jobs Improve Labor Market Outcomes for Low-Skilled Workers? Evidence from Random Assignments.” MIT Department of Economics Working Paper \#05-26.

Blank, Rebecca M. 1998. “Contingent Work in a Changing Labor Market” In Generating Jobs: How to Increase Demand for Less-Skilled Workers edited by Richard B. Freeman and Peter Gottschalk. New York: Russell Sage Foundation.

Booth, Alison L., Marco Francesconi, and Jeff Frank. 2002. “Temporary Jobs: Stepping Stones or Dead Ends?” Economic Journal 112 (June): F189-F213.

Davis-Blake, Alison and Brian Uzzi. 1993. "Determinants of Employment Externalization: A Study of Temporary Workers and Independent Contractors.” Administrative Science Quarterly 38 (June): 195-223.

García-Pérez, J. Ignacio, and Fernando Muñoz-Bullón. 2002. “The Nineties in Spain: Too Much Flexibility in the Labor Market.” Unpublished Paper, Universidad Carlos III de Madrid.

Heinrich, Peter B. Mueser, and Kenneth R. Troske. 2005. "Welfare to Temporary Work: Implications for Labor Market Outcomes.” Review of Economics and Statistics 87 (February): 154-173.

Houseman, Susan N., and Anne E. Polivka. 2000. "The Implications of Flexible Staffing Arrangements for Job Security.” In On the Job: Is Long-Term Employment a Thing of the Past? edited by David Neumark, pp. 427-462. New York: Russell Sage Foundation.

Ichino, Andre, Fabrizia Mealli, Tommasso Nanncini. 2004. "Temporary work Agencies in Italy: A Springboard Towards Permanent Employment? Unpublished Paper, European University Institute.

Kvasnicka, Michael. 2005. “Does Temporary Agency Work Provide a Stepping Stone to Regular Employment?” Unpublished Paper, Humboldt University of Berlin.

Lane, Julia, Kelly S. Mikleson, Pat Sharkey, and Doug Wissoker. 2003, "Pathways to Work for Low-Income Workers: The Effect of Work in the Temporary Help Industry.” Journal of Policy Analysis and Management 22 (Fall): 581-598.

Nollen, Stanley D. 1996. “Negative Aspects of Temporary Employment.” Journal of Labor Research 17 (Fall): 567-582. 
Official Journal. 1998. "Council Directive 97/81/EC of 15 December 1997 concerning the framework agreement on part-time work concluded by UNICE, CEEP and the ETUC.” Official Journal of the European Communities OJ L 14 of 20.1.1998.

Official Journal. 1999. Council Directive 97/70/EC of 28 June 1999 concerning the framework agreement on fixed-term work concluded by ETUC, UNICE and CEEP.” Official Journal of the European Communities OJ L 175 of 10.07.1999.

Official Journal. 2008. Directive 2008/104/EC of the European Parliament and of the Council of 19 November 2008 on temporary agency work. Official Journal of the European Communities OJ L 327 of 5.12.2008.

Parker, Robert E. 1994. Flesh Peddlers and Warm Bodies: The Temporary Help Industry and Its Workers. New Brunswick, N. J.: Rutgers University Press.

Polivka, Anne E., Sharon R. Cohany and Steven Hipple. 2000. "Definition, Composition, and Economic Consequences of the Nonstandard Workforce." In Nonstandard Work: The Nature and Challenges of Changing Employment Arrangements edited by Françoise J. Carré, Marianne A. Ferber, Lonnie Golden, and Stephen A. Herzenberg, pp. 41-94. Champaign, IL: Industrial Relations Research Association.

Segal, Lewis M., and Daniel G. Sullivan. 1997. “Temporary Services Employment Durations: Evidence From State UI Data.” Federal Reserve Bank of Chicago Working Paper 97-23.

Zijl, Marloes, Gerard J. van den Berg, and Arjan Heyma. 2004. "Stepping Stones for the Unemployed: The Effect of Temporary Jobs on the Duration until Regular Work." IZA Discussion Paper No. 1241. Bonn: Institute for the Study of Labor. 
TABLE 1

LABOR MARKET OUTCOMES ONE YEAR LATER, POOLED CEAS/CPS DATA

\begin{tabular}{|c|c|c|c|c|c|c|c|c|c|}
\hline & $\begin{array}{l}\text { Regular } \\
\text { workers }\end{array}$ & $\begin{array}{l}\text { Screened } \\
\text { workers }\end{array}$ & $\begin{array}{l}\text { Agency } \\
\text { temporaries }\end{array}$ & $\begin{array}{l}\text { Direct-hire } \\
\text { temporaries }\end{array}$ & $\begin{array}{l}\text { On-call } \\
\text { workers }\end{array}$ & $\begin{array}{l}\text { Contract } \\
\text { workers }\end{array}$ & $\begin{array}{l}\text { Independent } \\
\text { contractors }\end{array}$ & $\begin{array}{c}\text { Initially } \\
\text { unemployed }\end{array}$ & $\begin{array}{l}\text { Initially out of } \\
\text { labor force }\end{array}$ \\
\hline Employed & $91.3 \%$ & $92.2 \%$ & $80.7 \%$ & $85.3 \%$ & $82.7 \%$ & $91.6 \%$ & $89.5 \%$ & $56.5 \%$ & $18.3 \%$ \\
\hline Unemployed & 2.0 & 1.4 & 5.6 & 3.9 & 4.1 & 0.8 & 1.5 & 18.2 & 2.2 \\
\hline Out of labor force & 6.7 & 6.4 & 13.6 & 10.8 & 13.2 & 7.5 & 9.1 & 25.4 & 79.5 \\
\hline
\end{tabular}


TABLE 2

MULTINOMIAL LOGIT ANALYSES OF LABOR MARKET OUTCOMES ONE YEAR LATER, POOLED CAEAS/CPS DATA. (The base outcome is being unemployed one year later.)

\begin{tabular}{|c|c|c|c|c|}
\hline \multirow[b]{2}{*}{$\begin{array}{l}\text { Regular } \\
\text { workers }\end{array}$} & \multicolumn{2}{|c|}{$\begin{array}{c}\text { Employed } \\
\text { One Year Later }\end{array}$} & \multicolumn{2}{|c|}{$\begin{array}{l}\text { Out of Labor Force } \\
\text { One Year Later }\end{array}$} \\
\hline & 1 & $\begin{array}{l}2.218 * * * \\
(0.297) \\
{[0.224]}\end{array}$ & 1 & $\begin{array}{c}0.889 * * * \\
(0.323) \\
{[-0.178]}\end{array}$ \\
\hline $\begin{array}{l}\text { Screened } \\
\text { workers }\end{array}$ & $\begin{array}{c}0.295 \\
(0.224) \\
{[0.013]}\end{array}$ & $\begin{array}{l}2.513^{* * *} \\
(0.368) \\
{[0.237]}\end{array}$ & $\begin{array}{c}0.241 \\
(0.246) \\
{[-0.006]}\end{array}$ & $\begin{array}{c}1.130 * * * \\
(0.402) \\
{[-0.185]}\end{array}$ \\
\hline $\begin{array}{l}\text { Agency } \\
\text { temporaries }\end{array}$ & $\begin{array}{c}-0.393 \\
(0.255) \\
{[-0.100]}\end{array}$ & $\begin{array}{l}1.825^{* * *} \\
(0.387) \\
{[0.124]}\end{array}$ & $\begin{array}{c}0.281 \\
(0.285) \\
{[0.093]}\end{array}$ & $\begin{array}{l}1.170^{* * *} \\
(0.427) \\
{[-0.085]}\end{array}$ \\
\hline $\begin{array}{l}\text { Direct-hire } \\
\text { temporaries }\end{array}$ & $\begin{array}{l}-0.623 * * * \\
(0.119) \\
{[-0.072]}\end{array}$ & $\begin{array}{l}1.595^{* * *} \\
(0.313) \\
{[0.152]}\end{array}$ & $\begin{array}{l}-0.185 \\
(0.135) \\
{[0.059]}\end{array}$ & $\begin{array}{c}0.704 * * \\
(0.343) \\
{[-0.119]}\end{array}$ \\
\hline $\begin{array}{l}\text { On-call } \\
\text { workers }\end{array}$ & $\begin{array}{l}-0.533^{* *} \\
(0.225) \\
{[-0.081]}\end{array}$ & $\begin{array}{l}1.684 * * * \\
(0.369) \\
{[0.142]}\end{array}$ & $\begin{array}{l}-0.012 \\
(0.250) \\
{[0.071]}\end{array}$ & $\begin{array}{c}0.877^{* *} \\
(0.405) \\
{[-0.107]}\end{array}$ \\
\hline $\begin{array}{l}\text { Contract company } \\
\text { workers }\end{array}$ & $\begin{array}{c}0.768 \\
(0.717) \\
{[0.016]}\end{array}$ & $\begin{array}{l}2.986 * * * \\
(0.775) \\
{[0.239]}\end{array}$ & $\begin{array}{c}0.758 \\
(0.779) \\
{[0.002]}\end{array}$ & $\begin{array}{c}1.647^{*} \\
(0.842) \\
{[-0.177]}\end{array}$ \\
\hline $\begin{array}{l}\text { Independent } \\
\text { contractors }\end{array}$ & $\begin{array}{c}0.222 * \\
(0.132) \\
{[-0.023]}\end{array}$ & $\begin{array}{l}2.440 * * * \\
(0.315) \\
{[0.201]}\end{array}$ & $\begin{array}{l}0.419 * * * \\
(0.144) \\
{[0.029]}\end{array}$ & $\begin{array}{c}1.308^{* * *} \\
(0.342) \\
{[-0.150]}\end{array}$ \\
\hline $\begin{array}{l}\text { Initially } \\
\text { unemployed }\end{array}$ & $\begin{array}{l}-2.218 * * * \\
(0.297) \\
{[-0.224]}\end{array}$ & 1 & $\begin{array}{l}-0.889 * * * \\
(0.323) \\
{[0.178]}\end{array}$ & 1 \\
\hline $\begin{array}{l}\text { Initially out } \\
\text { of labor force }\end{array}$ & $\begin{array}{l}-1.326 * * * \\
(0.298) \\
{[-0.489]}\end{array}$ & $\begin{array}{c}0.892 * * * \\
(0.076) \\
{[-0.265]}\end{array}$ & $\begin{array}{l}2.065^{* * *} \\
(0.323) \\
{[0.472]}\end{array}$ & $\begin{array}{l}2.954 * * * \\
(0.080) \\
{[0.294]}\end{array}$ \\
\hline Tenure & & & & \\
\hline Tenure $^{2}$ & $\begin{array}{l}- \\
{[-}\end{array}$ & & & \\
\hline $\begin{array}{l}\text { Unemployment } \\
\text { rate }\end{array}$ & $\begin{array}{l}- \\
\text { [- }\end{array}$ & & & \\
\hline $\begin{array}{l}\text { Kids under } \\
\text { six years old }\end{array}$ & - & & & \\
\hline $\log L$ & & & & \\
\hline
\end{tabular}


$\beta_{\mathrm{AT}}=\beta_{\mathrm{DT}}:$

$\beta_{\mathrm{CW}}=\beta_{\mathrm{IC}}$ :

$\beta_{\mathrm{AT}}=\beta_{\mathrm{DT}}=\beta_{\mathrm{OC}}=\beta_{\mathrm{CW}}=\beta_{\mathrm{IC}}$ :

$\beta_{\mathrm{RW}}=\beta_{\mathrm{SW}}=\beta_{\mathrm{AT}}=\beta_{\mathrm{DT}}=\beta_{\mathrm{OC}}=\beta_{\mathrm{CW}}=\beta_{\mathrm{IC}}$ :
75,088

$$
\begin{array}{r}
\rho=2.89(\mathrm{p}=0.235) \\
\rho=1.03(\mathrm{p}=0.598) \\
\rho=43.00(\mathrm{p}=0.000) \\
\rho=101.68(\mathrm{p}=0.000)
\end{array}
$$

Notes: ${ }^{1}$ Denotes the reference category. All analyses include year dummies. Marginal effects are given in brackets. Additional controls are age (and age ${ }^{2}$ ), gender and ethnicity controls, a dummy variable equal to one if married (zero otherwise), an interaction term between gender (being female) and marital status, five educational dummies (omitted category is no high school diploma), a dummy variable equal to one if residing in an urban area (zero otherwise), four regional dummies (omitted category is living in the South), ten industry dummies (the omitted category is agriculture/fishing/forestry), and six occupational dummies (the omitted category is manager).

$* * *, * *, *$ denote statistical significance at the $0.01,0.05$, and 0.10 levels, respectively. 
TABLE 3

LABOR MARKET OUTCOMES FOR SELECTED WAVES OF THE NLSY79

\begin{tabular}{|c|c|c|c|c|c|c|c|c|}
\hline $\begin{array}{l}\text { Reg } \\
\text { worl }\end{array}$ & $\begin{array}{l}\text { ular } \\
\text { kers }\end{array}$ & $\begin{array}{l}\text { Screened } \\
\text { workers }\end{array}$ & $\begin{array}{c}\text { Agency } \\
\text { temporaries }\end{array}$ & $\begin{array}{l}\text { Direct-hire } \\
\text { temporaries }\end{array}$ & $\begin{array}{l}\text { Contractors/ } \\
\text { consultants }\end{array}$ & $\begin{array}{c}\text { Other } \\
\text { work types }\end{array}$ & $\begin{array}{c}\text { Initially } \\
\text { unemployed }\end{array}$ & $\begin{array}{l}\text { Initially out of } \\
\text { labor force }\end{array}$ \\
\hline \multicolumn{9}{|l|}{ (a) $1994-1996$} \\
\hline Employed & $92.0 \%$ & $93.0 \%$ & $77.9 \%$ & $79.2 \%$ & $87.9 \%$ & $85.4 \%$ & $68.7 \%$ & $35.0 \%$ \\
\hline Unemployed & 2.9 & 1.7 & 7.5 & 5.7 & 1.5 & 4.4 & 13.1 & 5.1 \\
\hline Out of labor force & 5.2 & 5.3 & 14.6 & 15.1 & 10.5 & 10.1 & 18.2 & 59.9 \\
\hline Fraction of time employed & 93.3 & 94.0 & 78.0 & 75.0 & 89.2 & 89.0 & 59.7 & 24.2 \\
\hline \multicolumn{9}{|l|}{ (b) $1998-2000^{1}$} \\
\hline Fraction of time employed & 94.2 & 96.1 & 80.9 & 77.8 & 95.2 & 90.3 & 40.6 & 18.8 \\
\hline \multicolumn{9}{|l|}{ (c) $1994-1998$} \\
\hline Employed & 91.4 & 92.9 & 79.4 & 83.7 & 88.2 & 86.0 & 72.4 & 44.4 \\
\hline Unemployed & 2.3 & 1.5 & 0.0 & 4.8 & 1.3 & 3.7 & 11.7 & 4.5 \\
\hline Out of labor force & 6.3 & 5.6 & 20.6 & 11.5 & 10.6 & 10.3 & 15.9 & 51.1 \\
\hline Fraction of time employed & 92.3 & 93.0 & 75.3 & 79.2 & 90.5 & 88.5 & 66.2 & 32.4 \\
\hline
\end{tabular}

Note: ${ }^{1}$ Labor market states past 1998 (i.e. 2000 and 2002) cannot be identified. See footnote 9. 
TABLE 4

MULTINOMIAL LOGIT ANALYSES OF LABOR MARKET OUTCOMES TWO EYARS LATER, NLSY79 DATA. (The base outcome is being unemployed two years later.)

\begin{tabular}{|c|c|c|c|c|}
\hline \multirow[b]{2}{*}{$\begin{array}{l}\text { Regular } \\
\text { workers }\end{array}$} & \multicolumn{2}{|c|}{$\begin{array}{c}\text { Employed } \\
\text { Two Years Later }\end{array}$} & \multicolumn{2}{|c|}{$\begin{array}{l}\text { Out of Labor Force } \\
\text { Two Years Later }\end{array}$} \\
\hline & 1 & $\begin{array}{l}1.127^{* * *} \\
(0.382) \\
{[0.091]}\end{array}$ & 1 & $\begin{array}{c}0.325 \\
(0.466) \\
{[-0.058]}\end{array}$ \\
\hline $\begin{array}{l}\text { Screened } \\
\text { workers }\end{array}$ & $\begin{array}{c}0.179 \\
(0.212) \\
{[0.016]}\end{array}$ & $\begin{array}{l}1.306^{* * *} \\
(0.437) \\
{[0.107]}\end{array}$ & $\begin{array}{c}0.023 \\
(0.260) \\
{[-0.011]}\end{array}$ & $\begin{array}{c}0.348 \\
(0.529) \\
{[-0.069]}\end{array}$ \\
\hline $\begin{array}{l}\text { Agency } \\
\text { temporaries }\end{array}$ & $\begin{array}{c}0.270 \\
(0.382) \\
{[-0.006]}\end{array}$ & $\begin{array}{l}1.397 * * \\
(0.540) \\
{[0.085]}\end{array}$ & $\begin{array}{c}0.453 \\
(0.453) \\
{[0.015]}\end{array}$ & $\begin{array}{c}0.777 \\
(0.650) \\
{[-0.043]}\end{array}$ \\
\hline $\begin{array}{l}\text { Direct-hire } \\
\text { temporaries }\end{array}$ & $\begin{array}{c}-0.271 \\
(0.386) \\
{[-0.064]}\end{array}$ & $\begin{array}{c}0.856 \\
(0.549) \\
{[0.027]}\end{array}$ & $\begin{array}{c}0.500 \\
(0.444) \\
{[0.058]}\end{array}$ & $\begin{array}{c}0.825 \\
(0.648) \\
{[-0.000]}\end{array}$ \\
\hline $\begin{array}{l}\text { Contractors/ } \\
\text { consultants }\end{array}$ & $\begin{array}{c}0.340 \\
(0.524) \\
{[-0.028]}\end{array}$ & $\begin{array}{l}1.467 * * \\
(0.648) \\
{[0.063]}\end{array}$ & $\begin{array}{c}0.848 \\
(0.566) \\
{[0.040]}\end{array}$ & $\begin{array}{c}1.173 \\
(0.724) \\
{[-0.019]}\end{array}$ \\
\hline $\begin{array}{l}\text { Other work } \\
\text { types }\end{array}$ & $\begin{array}{c}-0.601^{* *} \\
(0.251) \\
{[-0.050]}\end{array}$ & $\begin{array}{c}0.526 \\
(0.413) \\
{[0.041]}\end{array}$ & $\begin{array}{l}-0.148 \\
(0.297) \\
{[0.033]}\end{array}$ & $\begin{array}{c}0.177 \\
(0.508) \\
{[-0.025]}\end{array}$ \\
\hline $\begin{array}{l}\text { Initially } \\
\text { unemployed }\end{array}$ & $\begin{array}{l}-1.127 * * * \\
(0.382) \\
{[-0.091]}\end{array}$ & 1 & $\begin{array}{l}-0.325 \\
(0.466) \\
{[0.058]}\end{array}$ & 1 \\
\hline $\begin{array}{l}\text { Initially out } \\
\text { of labor force }\end{array}$ & $\begin{array}{c}-0.926 * * \\
(0.379) \\
{[-0.194]}\end{array}$ & $\begin{array}{c}0.202 \\
(0.140) \\
{[-0.104]}\end{array}$ & $\begin{array}{l}1.366^{* * *} \\
(0.457) \\
{[0.172]}\end{array}$ & $\begin{array}{l}1.690 * * * \\
(0.153) \\
{[0.114]}\end{array}$ \\
\hline Experience & & & & \\
\hline Experience $^{2}$ & & & $\begin{array}{r}0 \\
(0 \\
{[0}\end{array}$ & \\
\hline Tenure & & & & \\
\hline Tenure $^{2}$ & & & & \\
\hline
\end{tabular}


Jobs

$-0.083^{* * *}$

$-0.017$

$(0.027)$

$(0.017)$

[-0.007]

[0.005]

Kids under

$-0.001$

(0.064)

$0.195^{* * *}$

sixyears old

[-0.014]

(0.068)

[0.015]

$3-6 \%$ Local

$-0.552$

$-0.192$

unemployment rate

$(0.723)$

$(0.792)$

$[-0.042]$

[0.026]

6-9\% Local

$-0.697$

$-0.316$

$(0.721)$

$(0.791)$

[-0.048]

[0.027]

$9-12 \%$ Local

$-0.663$

$-0.079$

(0.735)

(0.806)

[-0.062]

[0.043]

12 - 15\% Local

$-0.791$

$-0.279$

unemployment rate

$(0.740)$

$(0.812)$

[-0.060]

[0.043]

$>15 \%$ Local

$-0.758$

$-0.216$

$(0.782)$

$(0.864)$

[-0.061]

[0.039]

$\log \mathrm{L}$

$-6,558.59$

$n$

15,355

$\beta_{\mathrm{AT}}=\beta_{\mathrm{DT}}:$

$\beta_{\mathrm{AT}}=\beta_{\mathrm{DT}}=\beta_{\mathrm{C} / \mathrm{C}}=\beta_{\mathrm{OWT}}:$

$\beta_{\mathrm{RW}}=\beta_{\mathrm{SW}}=\beta_{\mathrm{AT}}=\beta_{\mathrm{DT}}=\beta_{\mathrm{C} / \mathrm{C}}=\beta_{\mathrm{OWT}}:$

$$
\begin{array}{r}
\rho=1.06(p=0.304) \\
\rho=7.87(p=0.248) \\
\rho=26.36(p=0.003)
\end{array}
$$

Notes: ${ }^{1}$ Denotes the reference category. All analyses include year dummies. Marginal effects are given in brackets. Additional controls are age (and age ${ }^{2}$ ), gender and ethnicity controls, a dummy variable equal to one if married (zero otherwise), an interaction term between gender (being female) and marital status, education (in years), a dummy variable equal to one if residing in an urban area (zero otherwise), four regional dummies (omitted category is living in the South), ten industry dummies (the omitted category is agriculture/fishing/forestry), and six occupational dummies (the omitted category is manager).

$* * *, * *, *$ denote statistical significance at the $0.01,0.05$, and 0.10 levels, respectively. 
TABLE 5

MULTINOMIAL LOGIT ANALYSES OF LABOR MARKET OUTCOMES FOUR YEARS LATER, NLSY79 DATA (The base outcome is being unemployed four years later.)

\begin{tabular}{|c|c|c|c|c|}
\hline \multirow[b]{2}{*}{$\begin{array}{l}\text { Regular } \\
\text { workers }\end{array}$} & \multicolumn{2}{|c|}{$\begin{array}{c}\text { Employed } \\
\text { Four Years Later }\end{array}$} & \multicolumn{2}{|c|}{$\begin{array}{l}\text { Out of Labor Force } \\
\text { Four Years Later }\end{array}$} \\
\hline & 1 & $\begin{array}{l}1.075^{*} \\
(0.592) \\
{[0.119]}\end{array}$ & 1 & $\begin{array}{c}-0.112 \\
(0.712) \\
{[-0.095]}\end{array}$ \\
\hline $\begin{array}{l}\text { Screened } \\
\text { workers }\end{array}$ & $\begin{array}{c}0.724 * \\
(0.427) \\
{[0.022]}\end{array}$ & $\begin{array}{l}1.800 * * \\
(0.722) \\
{[0.141]}\end{array}$ & $\begin{array}{c}0.658 \\
(0.468) \\
{[-0.004]}\end{array}$ & $\begin{array}{c}0.547 \\
(0.843) \\
{[-0.099]}\end{array}$ \\
\hline $\begin{array}{l}\text { Temporary } \\
\text { workers }\end{array}$ & $\begin{array}{c}0.803 \\
(0.613) \\
{[0.015]}\end{array}$ & $\begin{array}{l}1.877 * * \\
(0.833) \\
{[0.134]}\end{array}$ & $\begin{array}{c}0.845 \\
(0.651) \\
{[0.005]}\end{array}$ & $\begin{array}{c}0.733 \\
(0.942) \\
{[-0.090]}\end{array}$ \\
\hline $\begin{array}{l}\text { Contractors/ } \\
\text { consultants }\end{array}$ & $\begin{array}{c}0.346 \\
(0.736) \\
{[-0.034]}\end{array}$ & $\begin{array}{c}1.422 \\
(0.930) \\
{[0.086]}\end{array}$ & $\begin{array}{c}0.865 \\
(0.790) \\
{[0.043]}\end{array}$ & $\begin{array}{c}0.753 \\
(0.942) \\
{[-0.052]}\end{array}$ \\
\hline $\begin{array}{l}\text { Other work } \\
\text { types }\end{array}$ & $\begin{array}{c}-0.732 * \\
(0.383) \\
{[-0.044]}\end{array}$ & $\begin{array}{c}0.343 \\
(0.649) \\
{[0.075]}\end{array}$ & $\begin{array}{l}-0.391 \\
(0.447) \\
{[0.026]}\end{array}$ & $\begin{array}{c}-0.503 \\
(0.782) \\
{[-0.069]}\end{array}$ \\
\hline $\begin{array}{l}\text { Initially } \\
\text { unemployed }\end{array}$ & $\begin{array}{c}-1.075 * \\
(0.592) \\
{[-0.119]}\end{array}$ & 1 & $\begin{array}{c}0.112 \\
(0.712) \\
{[0.095]}\end{array}$ & 1 \\
\hline $\begin{array}{l}\text { Initially out } \\
\text { of labor force }\end{array}$ & $\begin{array}{c}-0.944 \\
(0.587) \\
{[-0.204]}\end{array}$ & $\begin{array}{c}0.131 \\
(0.199) \\
{[-0.084]}\end{array}$ & $\begin{array}{c}1.325^{*} \\
(0.701) \\
{[0.184]}\end{array}$ & $\begin{array}{l}1.214 * * * \\
(0.216) \\
{[0.089]}\end{array}$ \\
\hline Experience & & & & \\
\hline Experience $^{2}$ & & & & \\
\hline Tenure & & & & \\
\hline Tenure $^{2}$ & & & & \\
\hline Jobs & & & & \\
\hline
\end{tabular}


Kids under

six years old

3-6\% Local

unemployment rate

6-9\% Local

unemployment rate

9 - 12\% Local

unemployment rate

12 - 15\% Local

unemployment rate

$>15 \%$ Local

unemployment rate

$\log \mathrm{L}$

$n$

$\beta_{\mathrm{AT}}=\beta_{\mathrm{DT}}:$

$\beta_{\mathrm{AT}}=\beta_{\mathrm{DT}}=\beta_{\mathrm{C} / \mathrm{C}}=\beta_{\mathrm{OWT}}:$

$\beta_{\mathrm{RW}}=\beta_{\mathrm{SW}}=\beta_{\mathrm{AT}}=\beta_{\mathrm{DT}}=\beta_{\mathrm{C} / \mathrm{C}}=\beta_{\mathrm{OWT}}$ :
0.069

(0.087)

[-0.008]

0.975

(1.073)

[0.055]

0.600

(1.073)

[0.049]

0.434

(1.080)

[0.029]

0.883

(1.118)

[0.053]

0.580

(1.161)

[0.038]

$-3,298.33$

7,401
$0.194 * *$

(0.091)

[0.011]

0.562

(1.148)

[-0.032]

0.161

(1.152)

[-0.035]

0.197

(1.156)

[-0.019]

0.477

(1.195)

[-0.031]

0.274

(1.244)

[-0.024]

Notes: ${ }^{1}$ Denotes the reference category; see Notes to Table 4. 
TABLE 6

OLS PANEL ESTIMATES OF EMPLOYMENT CONTINUITY, NLSY79 DATA. (The dependent variable is the fraction of time employed.)

\begin{tabular}{|c|c|c|c|c|c|c|c|c|}
\hline & \multicolumn{4}{|c|}{ Over Two Years } & \multicolumn{4}{|c|}{ "Over Four Years } \\
\hline & (1) & (2) & (3) & (4) & (5) & (6) & (7) & (8) \\
\hline $\begin{array}{l}\text { Regular } \\
\text { workers }\end{array}$ & 1 & $\begin{array}{l}22.071 * * * \\
(1.710)\end{array}$ & 1 & $\begin{array}{l}8.475^{* * *} \\
(1.994)\end{array}$ & 1 & $\begin{array}{l}9.706^{* * *} \\
(1.618)\end{array}$ & 1 & $\begin{array}{c}2.196 \\
(2.109)\end{array}$ \\
\hline $\begin{array}{l}\text { Screened } \\
\text { workers }\end{array}$ & $\begin{array}{c}0.844^{*} \\
(0.512)\end{array}$ & $\begin{array}{l}22.916^{* * *} \\
(1.756)\end{array}$ & $\begin{array}{c}0.453 \\
(0.586)\end{array}$ & $\begin{array}{l}8.929 * * * \\
(2.037)\end{array}$ & $\begin{array}{c}0.211 \\
(0.471)\end{array}$ & $\begin{array}{l}9.918^{* * *} \\
(1.655)\end{array}$ & $\begin{array}{l}-0.083 \\
(0.543)\end{array}$ & $\begin{array}{c}2.112 \\
(2.152)\end{array}$ \\
\hline $\begin{array}{l}\text { Agency } \\
\text { temporaries }\end{array}$ & $\begin{array}{l}-4.178 * * \\
(1.996)\end{array}$ & $\begin{array}{l}17.893^{* * * *} \\
(2.594)\end{array}$ & $\begin{array}{l}-1.287 \\
(2.069)\end{array}$ & $\begin{array}{l}\text { 7.189** } \\
(2.836)\end{array}$ & $\begin{array}{l}-1.865 \\
(1.801)\end{array}$ & $\begin{array}{l}7.841^{* *} \\
(2.296)\end{array}$ & $\begin{array}{l}-1.021 \\
(1.990)\end{array}$ & $\begin{array}{c}1.175 \\
(2.874)\end{array}$ \\
\hline $\begin{array}{l}\text { Direct-hire } \\
\text { temporaries }\end{array}$ & $\begin{array}{l}-8.452^{* * *} \\
(2.181)\end{array}$ & $\begin{array}{l}13.620^{* * *} \\
(2.812)\end{array}$ & $\begin{array}{l}-4.855^{* * *} \\
(2.247)\end{array}$ & $\begin{array}{c}3.620 \\
(3.059)\end{array}$ & $\begin{array}{l}-4.494^{* * *} \\
(1.661)\end{array}$ & $\begin{array}{l}5.212^{* *} \\
(2.367)\end{array}$ & $\begin{array}{l}-2.224 \\
(1.780)\end{array}$ & $\begin{array}{l}-0.025 \\
(2.780)\end{array}$ \\
\hline $\begin{array}{l}\text { Contractors/ } \\
\text { consultants }\end{array}$ & $\begin{array}{c}0.264 \\
(0.992)\end{array}$ & $\begin{array}{l}22.336^{* * *} \\
(1.950)\end{array}$ & $\begin{array}{l}-0.327 \\
(0.990)\end{array}$ & $\begin{array}{l}8.802^{* * *} \\
(2.201)\end{array}$ & $\begin{array}{c}0.461 \\
(1.036)\end{array}$ & $\begin{array}{l}10.167^{* * * *} \\
(1.872)\end{array}$ & $\begin{array}{l}-0.859 \\
(1.158)\end{array}$ & $\begin{array}{c}3.055 \\
(2.341)\end{array}$ \\
\hline $\begin{array}{l}\text { Other work } \\
\text { types }\end{array}$ & $\begin{array}{l}-3.568^{* * *} \\
(1.055)\end{array}$ & $\begin{array}{l}18.503^{* * *} \\
(1.954)\end{array}$ & $\begin{array}{l}-2.783^{* *} \\
(1.086)\end{array}$ & $\begin{array}{l}5.692 * * \\
(2.219)\end{array}$ & $\begin{array}{l}-2.821^{* * *} \\
(0.910)\end{array}$ & $\begin{array}{l}6.886^{* * * *} \\
(1.793)\end{array}$ & $\begin{array}{l}-1.460 \\
(0.984)\end{array}$ & $\begin{array}{c}0.735 \\
(2.256)\end{array}$ \\
\hline $\begin{array}{l}\text { Initially } \\
\text { unemployed }\end{array}$ & $\begin{array}{l}-22.071^{* * *} \\
(1.170)\end{array}$ & 1 & $\begin{array}{l}-8.475^{* * *} \\
(1.994)\end{array}$ & 1 & $\begin{array}{l}-9.706^{* * *} \\
(1.618)\end{array}$ & 1 & $\begin{array}{l}-2.196 \\
(2.109)\end{array}$ & 1 \\
\hline $\begin{array}{l}\text { Initially out } \\
\text { of labor force }\end{array}$ & $\begin{array}{l}-45.019 * * * \\
(1.496)\end{array}$ & $\begin{array}{l}-22.948 * * * \\
(1.386)\end{array}$ & $\begin{array}{l}-18.969 * * * \\
(1.917)\end{array}$ & $\begin{array}{l}-10.494^{* * *} \\
(1.375)\end{array}$ & $\begin{array}{l}-24.005^{* * * *} \\
(1.526)\end{array}$ & $\begin{array}{l}-14.299 * * * \\
(1.108)\end{array}$ & $\begin{array}{l}-6.935^{* * *} \\
(2.042)\end{array}$ & $\begin{array}{l}-4.740 * * * \\
(1.158)\end{array}$ \\
\hline Experience & $\begin{array}{r}3.70 \\
(0.18\end{array}$ & $\begin{array}{l}6 * * * \\
66)\end{array}$ & $\begin{array}{r}-10.8 \\
(0.5\end{array}$ & $\begin{array}{l}40^{* *} \\
52)\end{array}$ & $\begin{array}{r}4.42 \\
(0.21\end{array}$ & $\begin{array}{l}22 * * * \\
18)\end{array}$ & $\begin{array}{l}-9.4 \mathrm{C} \\
(0.56\end{array}$ & $\begin{array}{l}3 * * * \\
9)\end{array}$ \\
\hline Experience $^{2}$ & $\begin{array}{l}-0.10 \\
(0.00\end{array}$ & $\begin{array}{l}3 * * * \\
7)\end{array}$ & $\begin{array}{r}0.0 \\
(0.0\end{array}$ & & $\begin{array}{l}-0.12 \\
(0.00\end{array}$ & $\begin{array}{l}21 * * * \\
08)\end{array}$ & $\begin{array}{r}0.03 \\
(0.01\end{array}$ & $\begin{array}{l}3 * * * \\
4)\end{array}$ \\
\hline Tenure & $\begin{array}{r}0.33 \\
(0.09\end{array}$ & $\begin{array}{l}35 * * * \\
96)\end{array}$ & $\begin{array}{l}-0.8 \\
(0.12\end{array}$ & $\begin{array}{l}64 * * * \\
24)\end{array}$ & $\begin{array}{l}-0.32 \\
(0.09\end{array}$ & $\begin{array}{l}24 * * * \\
93)\end{array}$ & $\begin{array}{l}-0.72 \\
(0.12\end{array}$ & ) \\
\hline
\end{tabular}




\begin{tabular}{|c|c|c|c|c|}
\hline Tenure $^{2}$ & $\begin{array}{l}-0.014^{* *} \\
(0.006)\end{array}$ & $\begin{array}{l}0.040^{* * *} \\
(0.008)\end{array}$ & $\begin{array}{l}0.022^{* * *} \\
(0.006)\end{array}$ & $\begin{array}{l}0.038^{* * *} \\
(0.008)\end{array}$ \\
\hline Jobs & $\begin{array}{l}-0.245 \\
(0.149)\end{array}$ & $\begin{array}{l}4.778^{* * *} \\
(0.902)\end{array}$ & $\begin{array}{l}-0.460 * * \\
(0.211)\end{array}$ & $\begin{array}{l}3.461^{* * *} \\
(0.639)\end{array}$ \\
\hline $\begin{array}{l}\text { Kids under } \\
\text { six years old }\end{array}$ & $\begin{array}{l}-1.190 * * * \\
(0.217)\end{array}$ & $\begin{array}{l}-0.578^{*} \\
(0.301)\end{array}$ & $\begin{array}{l}-1.193^{* * * *} \\
(0.224)\end{array}$ & $\begin{array}{l}-0.654 * * \\
(0.201)\end{array}$ \\
\hline $\begin{array}{l}3-6 \% \text { Local } \\
\text { unemployment rate }\end{array}$ & $\begin{array}{l}-0.003 \\
(0.600)\end{array}$ & $\begin{array}{l}-0.147 \\
(0.684)\end{array}$ & $\begin{array}{c}0.129 \\
(0.545)\end{array}$ & $\begin{array}{l}-0.130 \\
(0.669)\end{array}$ \\
\hline $\begin{array}{l}6-9 \% \text { Local } \\
\text { unemployment rate }\end{array}$ & $\begin{array}{l}-0.082 \\
(0.673)\end{array}$ & $\begin{array}{l}-0.115 \\
(1.382)\end{array}$ & $\begin{array}{l}-0.225 \\
(0.629)\end{array}$ & $\begin{array}{l}-0.277 \\
(0.794)\end{array}$ \\
\hline $\begin{array}{l}9-12 \% \text { Local } \\
\text { unemployment rate }\end{array}$ & $\begin{array}{l}-0.380 \\
(0.824)\end{array}$ & $\begin{array}{c}0.714 \\
(1.029)\end{array}$ & $\begin{array}{l}-0.920 \\
(0.765)\end{array}$ & $\begin{array}{l}-0.096 \\
(0.970)\end{array}$ \\
\hline $\begin{array}{l}12-15 \% \text { Local } \\
\text { unemployment rate }\end{array}$ & $\begin{array}{l}-0.811 \\
(0.933)\end{array}$ & $\begin{array}{c}0.741 \\
(1.062)\end{array}$ & $\begin{array}{l}-0.455 \\
(0.792)\end{array}$ & $\begin{array}{c}0.578 \\
(0.945)\end{array}$ \\
\hline $\begin{array}{l}>15 \% \text { Local } \\
\text { unemployment rate }\end{array}$ & $\begin{array}{l}1.098 \\
(1.520)\end{array}$ & $\begin{array}{l}4.133^{*} \\
(2.332)\end{array}$ & $\begin{array}{c}0.405 \\
(1.678)\end{array}$ & $\begin{array}{l}0.820 \\
(2.442)\end{array}$ \\
\hline $\mathrm{R}^{2}$ & 0.60 & 0.21 & 0.53 & 0.27 \\
\hline$n$ & 22,644 & 22,644 & 21,109 & 21,109 \\
\hline Model & $\mathrm{RE}$ & $\mathrm{FE}$ & $\mathrm{RE}$ & FE \\
\hline$\beta_{\mathrm{AT}}=\beta_{\mathrm{DT}}:$ & $\rho=2.17(p=0.141)$ & $\rho=0.93(p=0.336)$ & $\rho=1.28(\mathrm{p}=0.259)$ & $\rho=0.23(p=0.631)$ \\
\hline$\beta_{\mathrm{AT}}=\beta_{\mathrm{DT}}=\beta_{\mathrm{C} / \mathrm{C}}=\beta_{\mathrm{OWT}}:$ & $\rho=17.55(p=0.001)$ & $\rho=1.67(p=0.243)$ & $\rho=9.75(p=0.021)$ & $\rho=1.21(p=0.306)$ \\
\hline$\beta_{\mathrm{RW}}=\beta_{\mathrm{SW}}=\beta_{\mathrm{AT}}=\beta_{\mathrm{DT}}=\beta_{\mathrm{ClC}}=\beta_{\mathrm{OWT}}:$ & $\rho=34.32(p=0.000)$ & $\rho=1.62(p=0.150)$ & $\rho=9.73(p=0.021)$ & $\rho=0.99(p=0.422)$ \\
\hline
\end{tabular}

